MOŽNOSTI VYUŽITÍ ŠKÁLY ČTYŘ ÚROVNÍ ČTENÁŘSKÉ GRAMOTNOSTI PIRLS $2016 \mathrm{~V}$ PROBLEMATICE ČTENÍ S POROZUMĚNÍM K ROZVOJI SLOŽITĚJŠÍCH ČTENÁŘSKÝCH DOVEDNOSTÍ PŘI PRÁCI S UMĚLECKÝM TEXTEM V HODINÁCH LITERÁRNÍ VÝCHOVY A ČTENÍ NA 1. STUPNI ZŠ.

POSSIBILITIES OF USING THE SCALE OF FOUR LEVELS OF READING LITERACY PIRLS 2016 IN THE ISSUE OF READING COMPREHENSION TO DEVELOP MORE COMPLEX READING SKILLS WHEN WORKING WITH ARTISTIC TEXT IN LITERARY EDUCATION CLASSES AND READING AT THE 1ST STAGE OF ELEMENTARY SCHOOL.

\title{
Blanka Janáčková ${ }^{1}$ \\ ${ }^{1}$ Univerzita Jana Evangelisty Purkyně v ústí nad Labem, Česká republika
}

OJPPE 1 (1) - Recenzované články/Reviewed Papers [styl DOI]

Publikováno/Published dne 5. 12. 2015

DOI: 10.21062/edp.2020.003

\begin{abstract}
Abstrakt
Obsah článku vychází z mezinárodního šetření PIRLS (Progress in International Reading Literacy Study) 2016 ke čtenářské gramotnosti žáků 4. ročníků při čtení literárních textů. Představuje náměty na didaktické postupy při práci s žáky základní školy $v$ hodinách literární výchovy a čtení s uměleckými texty dětské literatury. Uvedené úrovně ve škále čtenářské gramotnosti PIRLS 2016 byly využity při interpretaci typického žánru dětské literatury - pohádky lidové a autorské. Cílem článku je popsat možnosti, jak postupovat při práci s uměleckým textem v jednotlivých úrovních čtenářské gramotnosti a jak nakládat v hodinách literární výchovy a čtení na 1. stupni ZŠ s informacemi, které šetření přináší, $v$ konkrétních didaktických situacích při interpretaci vhodně zvolených literárních textů.
\end{abstract}

Klíčová slova: Čtenářská gramotnost, literární gramotnost, úrovně čtenářské gramotnosti PIRLS 2016, umělecký text

\begin{abstract}
The content of the article is based on the PIRLS (Progress in International Reading Literacy Study) 2016 to readers' reading literacy of 4th year students when reading literary texts. It presents ideas for didactic procedures when working with elementary school pupils in classes of literary education and reading with artistic texts of children's literature. These levels in the PIRLS 2016 reading literacy scale were used to interpret a typical genre of children's literature - folk and author's fairy tales. The aim of the article is to describe the possibilities of how to work with the artistic text at individual levels of reading literacy and how to handle literary education and reading at elementary school with the information that the survey brings in specific didactic situations when interpreting appropriately chosen literary texts.
\end{abstract}

Keywords: Reading literacy, literary literacy, levels of reading literacy PIRLS 2016, literary text 


\section{ÚVOD}

V souvislosti s dětským čtenářstvím, jeho rozvíjením a podporou, je důležité zdůraznit nutnost spolupráce všech kompetentních subjektů, jež by se na posilování čtenářství našich žáků měli účastnit. Aktivní dětské čtenářství je podmíněno dobrou orientací v psaném textu. Proto je nutné približit i učitelské veřejnosti, která se na rozvíjení čtenářské gramotnosti $v$ nemalé míre podílí, současný stav úrovně čtenářské gramotnosti žáků mladšího školního věku tak, jak je nyní dostupný z výsledků šetření PIRLS. Česká školní inspekce pořádá informační semináře $k$ výsledkům Mezinárodního šetření PIRLS 2016, jež se konkrétně týkají čtenářské gramotnosti žáků 4. ročníku základní školy. Účastníci se mohou na těchto setkáních seznámit se zajímavými závěry, které projekt nabídl, a následně najít východiska, jak dále se sdělenými informacemi nakládat ve své profesi.

Šetření mezinárodního projektu Progress in International Reading Literacy Study (PIRLS), který byl zaměřen na čtenářskou gramotnost žáků 4. ročníku škol, probíhá pravidelně od roku 2001 v pětiletých intervalech. Cílem je zjistit, jaká je úroveň čtenářských dovedností žáků, a zda v průběhu let minulých do současnosti došlo $v$ této problematice $\mathrm{k}$ určitému vývoji. Česká republika se šetření s výjimkou roku 2006 pravidelně účastní a závěry, které z projektu vyplývají, prostřednictvím České školní inspekce veřejnosti zprostředkovává.

Výsledky, které byly zjištěny a zveřejněny, Ize studovat v publikaci Mezinárodní šetření PIRLS 2016, Národní zpráva. Struktura materiálu seznamuje v několika kapitolách s výsledky českých žáků základních škol a v oblasti čtenářské gramotnosti s jejich vývojem v mezinárodním kontextu. $\vee$ průběhu sledovaných let (2001-2016) došlo u našich žáků v oblasti čtenářské gramotnosti k výraznému zlepšení, ale od posledního šetření v roce $2011 \mathrm{v}$ následujících letech poněkud ve výsledcích naši žáci stagnovali. V testu, kterému se poté podrobili v roce 2016, dosáhli $v$ porovnání $s$ výsledky žáků jiných států již nadprůměrného výsledku. Celková škála čtenášské gramotnosti byla vytvořena v šetření PIRLS 2016 na základě výsledků zemí, které se tehdy šetření účastnily. Škála byla nastavena tak, aby mezinárodní průměr odpovídal hodnotě 500 bodů a směrodatná odchylka byla 100 bodů. Výsledky každého dalšího cyklu šetření PIRLS jsou přepočítávány na tuto škálu, aby bylo možné porovnávat jejich vývoj v čase. Hodnota 500 bodů tvoří střed škály, který odpovídá původnímu mezinárodnímu průměru. Vzhledem $\mathrm{k}$ měnícímu se složení zúčastněných zemí může mezinárodní průměr v každém dalším cyklu dosahovat jiné hodnoty než 500. Obrázek ukazuje že, z průměru na celkové škále získali naši žáci z možných 500 bodů se směrodatnou odchylkou 100 bodů 543 bodů. $V$ porovnání s ostatními zúčastněnými zeměmi - Rusko (581) a Singapur (576), které se umístily nejvýše, zůstali za našimi žáky testovaní žáci z Rakouska (541), Německa (537) i Slovenska (535) ${ }^{1}$.

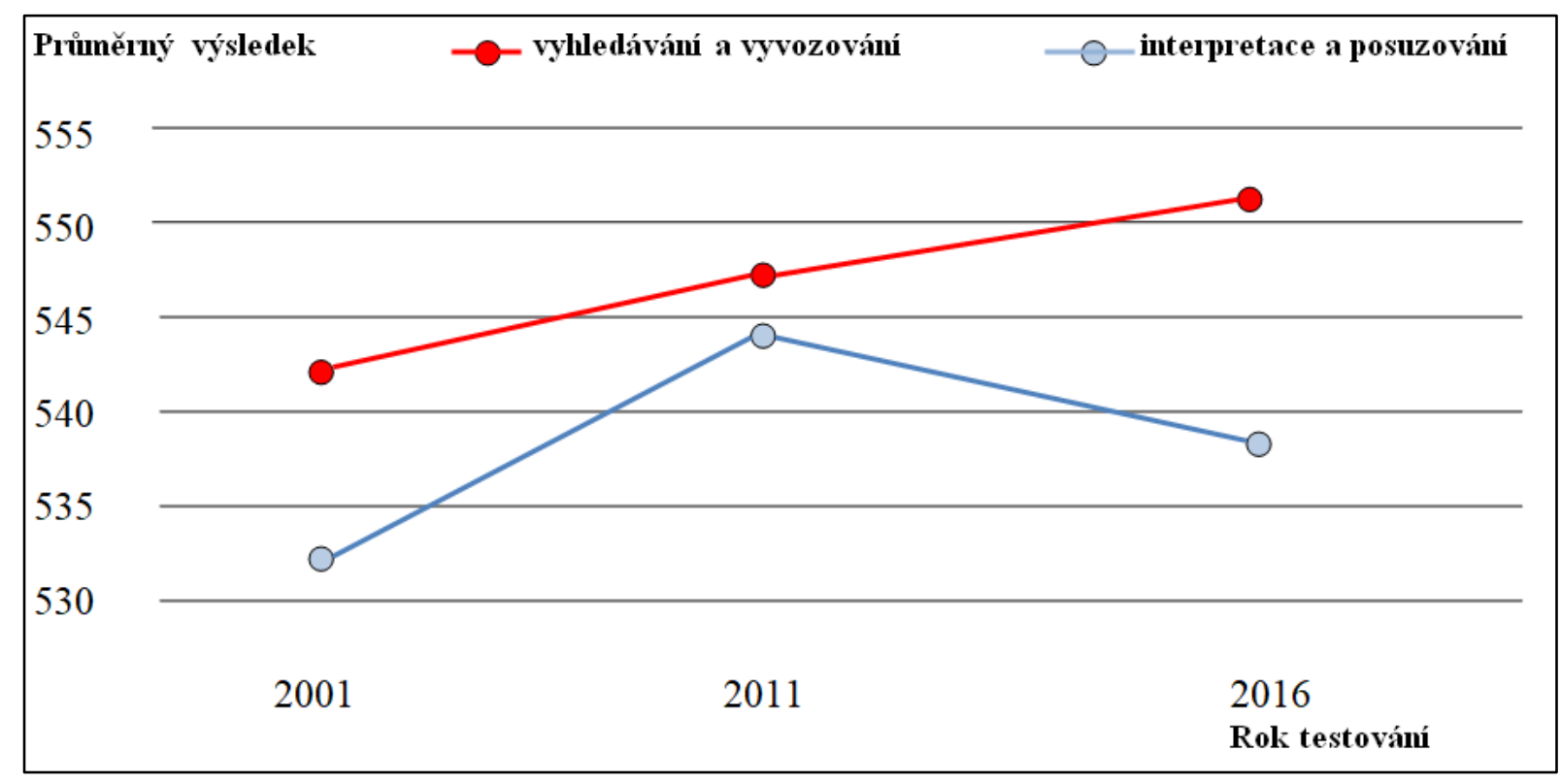

Obr. 1: Vývoj výsledků ČR na škálách podle postupů porozumění od roku 2001.

\footnotetext{
${ }^{1}$ Mezinárodní šetření PIRLS 2016, Národní zpráva MŠMT, s. 10. ISBN 978-80-88087-14-4.
} 
Na obrázku je znázorněn vývoj výsledků českých žáků na dílčích škálách podle postupů porozumění od roku 2001. Zatímco na škále vyhledávání a vyvozování se za posledních 15 let čeští žáci průběžně zlepšovali, na škále interpretace a posuzování se zlepšili pouze mezi lety 2001 a 2011, pak se jejich výsledek opět zhoršil. Souhrnně se nerovnoměrný vývoj ve sledovaných dvou oblastech čtenářské gramotnosti projevil stagnací celkového výsledku mezi lety 2011 a $2016 .^{2}$

V testu zadané úkoly, které respektují koncept čtenářské gramotnosti v šetření PIRLS, byly zaměřeny při čtení literárních textů na: a) vyhledávání explicitě uvedených informací, b) vyvozování závěrů, c) interpretaci a integraci myšlenek a informací, d) zkoumání a vyhodnocování obsahu, jazyka a prvků textu. Podívejme se na problematiku čtenářské gramotnosti do současných odborných zdrojů.

V odborné literatuře se různí definice čtenářské gramotnosti. V Pedagogickém slovníku je uvedeno ${ }^{3}$ : je to „komplex vědomostí a dovedností jedince, které mu umožňují zacházet s písemnými texty běžně se vyskytujícími $v$ životní praxi (např. železniční rád, návod k užívání léku). Jde o dovednosti nejen čtenářské, tj. umět texty prečist a rozumět jim, ale také o dovednosti vyhledávat, zpracovávat, srovnávat informace obsažené v textu, reprodukovat obsah textu aj.".

V jiném zdroji ${ }^{4}$ nalezneme. "Čtenářská gramotnost zahrnuje nejen osvojení si dovednosti čtení, ale schopnost pracovat s textem, komunikovat prostřednictvím psané řeči, získávat a zpracovávat informace z textu atd."

Pro výzkum PIRLS je čtenářská gramotnost vnímána jako „schopnost rozumět formám psaného jazyka, které vyžaduje společnost a/nebo oceňuji jednotlivci, a tyto formy použivat. Mladí čtenáři mohou odvozovat význam z široké škály textů. Čtou, aby se zapojili do společenství čtenárư a pro zábavu. " ${ }^{5}$

Zvolili jsme pouze některé z výkladů, které dokládají, že pro termín čtenářská gramotnost nemáme žádnou stabilní definici, která by se dala používat v širokém spektru společenského užití. Společnost se vyvijí ve všech svých sférách poměrně rychle. Přikloníme se tedy $k$ definici, jež na základě posledních mezinárodních výzkumů OECD PISA ${ }^{6}$, v němž byl kladen důraz na schopnost čtenáře textu porozumět, přemýšlet o něm přemýšlet, využít svých vlastních myšlenek a zkušeností, nejlépe popisuje čtenářskou gramotnost. „Čtenářská gramotnost znamená schopnost porozumět psanému textu, přemýšlet o něm a používat jej $k$ dosahování určitých cílů, $k$ rozvoji vlastních schopností a vědomostí a k aktivnímu začlenění do života společnosti.

V souvislosti s gramotností využíváme i termínu funkční gramotnost, kterou dohledáme jako „vybavenost člověka pro realizaci různých aktivit vyžadovaných současnou civilizací. Je to např. dovednost nejen číst, ale také chápat složitější texty, vyplnit formulář, zformulovat písemnou žádost apod. "7

Funkční gramotnost Ize rozdělit do tři složek, na gramotnost textovou (literární), dokumentovou a numerickou. ${ }^{8}$ Gramotnost textová (literární) v pojetí didaktickém sleduje dovednost žáka pracovat s texty, které vycházejí z dětské četby, tedy s psanými, respektive tištěnými, texty, které žákům 1. stupně základní školy nabízejí v současné době všechny čítanky užívané na základních školách. V těchto učebnicích určené pro čtení, je dostupné široké spektrum žánrů, jež si mají žáci osvojit, v rozsahu od převážně snadných až po ty poměrně obtížné.

Složku funkční gramotnosti Ize posoudit u žáků 1. stupně základní školy na základě kroků, které vycházejí z konceptu čtenářské gramotnosti šetření PIRLS, Tyto kroky Ize rozčlenit do úloh, které charakterizují dovedností na dané čtenářské úrovni.

\footnotetext{
${ }^{2}$ Mezinárodní šetření PIRLS 2016, Národní zpráva MŠMT, s. 23. ISBN 978-80-88087-14-4.

${ }^{3}$ PRŮCHA, J.; WALTEROVÁ, E.; MAREŠ, J. Pedagogický slovník. Praha: Portál, 2009, s. 42. ISBN 80-7178-579-2.

${ }^{4}$ PRŮCHA, J. a kol. Pedagogická encyklopedie. Praha: Portál, 2009, s. 230. ISBN 80-7178-579-2.

${ }^{5}$ Text převzat z: Metelková Svobodová, R. Čtenářská gramotnost z lingvistického hlediska. Ostrava: UNIVERSITAS, 2008. s. 10. ISBN 978-80-7367-653-6.

${ }^{6}$ OECD PISA - výzkum čtenářské gramotnosti pod zkratkou PISA (Programme for International Student Assessment) organizuje od roku $2000 \mathrm{v}$ pravidelných tř́letých cyklech Organizace pro hospodářskou spolupráci a rozvoj (OECD).

${ }^{7}$ PRŮCHA, J.; WALTEROVÁ, E.; MAREŠ, J. Pedagogický slovník. Praha: Portál, 2009, s. 67. ISBN 80-7178-579-2.

${ }^{8}$ Použito z: METELKOVÁ SVOBODOVÁ, R., HYPLOVÁ, J. Strategie rozvíjení čtenářské gramotnosti v čitankách 1. stupně ZŠ. Ostrava: UNIVERSITAS, 2011, s. 17. ISBN 978-80-7464-003-2.
} 
Žák s nizkou úrovní čtenářské gramotnosti by měl být schopen při čtení prèevážně snadných literárních textů plnit úlohy zaměřené na vyhledávání explicitně vyjádřených informací, události či myšlenky, vyvodit bezprostřední závěry o událostech a př́činách jednání a jednoduše interpretovat události príběhu nebo jeho hlavní myšlenku.

Střední úroveň čtenářské gramotnosti při čtení snadných i poměrně obtižných literárních textů by měl být žák schopen samostatně vyhledat a reprodukovat explicitně popsané události, jednání a pocity postav, vyvodit bezprostřední závěry týkající se vlastností, pocitů a pohnutek hlavních postav a interpretovat zrejmé důvody a príčiny a své interpretace podložit vhodnými príklady z textu.

Při čtení poměrně obtižných literárních textů ve vysoké úrovni čtenářské gramotnosti by měl žák zvládnout úlohy, jejichž prostřednictvím dokáže rozpoznat a vyhledat podstatné skutečnosti a detaily zmíněné na různých místech $v$ textu, s odkazem na text vyvozovat závěry o vztazích mezi událostmi, záměry, jednáním a pocity postav, interpretovat a propojit události príběhu s jednáním, vlastnostmi a měnícími se pocity postav. $\checkmark$ neposlední řadě také rozpoznat použití některých jazykových prostředků (např. metafory, citového zabarvení obrazného vyjádření.

Velmi vysoká úroveň prokázání čtenářské gramotnosti při čtení poměrně obtižných literárních textů je zřejmá, když žák umí interpretovat události príběhu a jednání postav a s přesným odkazem na text popsat príčiny událostí, pohnutky a pocity postav $\mathrm{i}$ jejich postupný vývoj v př́iběhu, jednoduše posoudit výběr jazykových a stylistických prostředků a jejich působení na čtenáře. Viz príloha 1.

Při zkoumání závěrů nás zaujal výstup z šetření, který je věnován výsledkům žáků na dílčích škálách čtenářské gramotnosti. Naši pozornost poutala zejména zjištěná data, která se týkala zhodnocení výkonů žáků v oblasti práce $s$ literárními texty. $V$ těch si, na rozdíl od textů informačního charakteru, naši žáci vedli poněkud lépe.

V šetření PIRLS, v němž se hodnotí čtenářská gramotnost, byly sledovány dvě položky. Účel čtení a postupy porozumění. Výsledky žákủ byly porovnávány na šesti literárních a šesti informačních textech. Z pohledu literární gramotnosti měli žáci 4. ročníkủ pro získání literární zkušenosti prokázat dovednosti, které jim umožnily porozumět jeho významu. Byly to dovednosti využitelné v postupech dovedností: vyhledávání informací, vyvozování závěrů, interpretaci a posuzování textu.

Tabulka naznačuje, že na škále literárních textů (modrý motiv na obrázku), jak podle účelu čtení, tak i podle využitých postupů porozumění, bylo možné posoudit v porovnání s ostatními účastníky šetření, úroveň českých žáků.

Tab. 1: Dílčí škály pro prezentaci výsledkủ šetření PIRLS (upraveno) ${ }^{9}$

\begin{tabular}{|l|l|}
\hline \multirow{2}{*}{ Dílčí škály podle účelu čtení } & Škála čtení pro získání literární zkušenosti (škála literárních textů) \\
\cline { 2 - 2 } & Škála čtení pro získání a používání informací (škála informačních textů) \\
\hline \multirow{2}{*}{$\begin{array}{l}\text { Dílčí škály podle využitých } \\
\text { postupů porozumění }\end{array}$} & Škála vyhledávání informací a vyvozování závěrů (škála vyhledávání a vyvozování) \\
\cline { 2 - 3 } & $\begin{array}{l}\text { Škála interpretace a posuzování textu (škála interpretace } \\
\text { a posuzování) }\end{array}$ \\
\hline
\end{tabular}

Podle účelu čtení dosáhli naši žáci 4. ročníků základních škol na škále literárních textů 545 bodů a podle postupů porozumění na škále vyhledávání a vyvozování 551 bodů a na škále interpretace a posuzování 538 bodů. Naši žáci si tedy lépe vedou při vyhledávání a vyvozování závěrů z literárního textu a poněkud horší výsledky dosahují při interpretaci a posuzování literárního textu.

\footnotetext{
${ }^{9}$ Mezinárodní šetření PIRLS 2016, Národní zpráva MŠMT, s. 18. ISBN 978-80-88087-14-4.
} 


\section{METODOLOGIE VYUŽITÍ VÝSLEDKU゚ ŠETŘENÍ PIRLS 2016 PŘI PRÁCI S POHÁDKOVÝMI TEXTY DĚTSKÉ LITERATURY}

Testovaným žákům byly předloženy literární a informační texty v úrovni od převážně snadných až po poměrně obtižné a k nim byly zadány úkoly nízké, střední, vysoké a velmi vysoké úrovně. My se zajímáme zejména o výsledky, kterých naši žáci dosáhli v oblasti čtenářské gramotnosti zaměřené na úroveň čtenářské gramotnosti při čtení literárních textů. Využili jsme zjištěných výsledků šetření PIRLS 2016 a na konkrétních ukázkách z dětské literatury jsme popsali možné postupy při práci s literárním textem, abychom podpořili v problematice čtení s porozuměním rozvoj složitějších čtenářských dovedností žáků 1. stupně základní školy. Východiskem pro nás byl oblíbený žánr dětské četby - pohádka, a to jak v její podobě lidové, tak i ve zpracování autorském. V následujícím textu našeho příspěvku předkládáme náměty na prohlubování čtenářské gramotnosti z hlediska vyhledávání, rozpoznání podstatných skutečností a následného interpretování čteného literárního textu.

Pokud se tedy zaměříme na vyhledávání ve škále využitých postupů porozumění, měli bychom nadále ve školní praxi prostřednictvím literárních textů s žáky pracovat přiměřeně jejich schopnostem a dovednostem. Měli bychom ale také z hlediska respektování čtenářské kompetence, zvyšovat požadavky tak, aby vždy mírně přesahovaly žákovy aktuální kompetence. Využijeme-li pohádkového textu Jiř́iho Horáka Honza a vrba (458 slov $)^{10}$, zaměříme se konkrétně na vyhledání postav pohádky. "Najdi pohádkové postavy, které v príběhu vystupuji." Určujeme také na základě získaných informací prostředí a dobu př́běhu. "Na kterých místech se pohádkový príběh odehrává?; "Kam Honza došel, když ve světě plátno neprodal?“; "Kde Honza našel hrnec stolary a dukáty?" Zároveň žák o nalezené informaci vyvozuje bezprostřední závěr. "Je to pohádkový, nekonkrétní svět.", v neurčitém čase, jenž je uvedený slovním spojením „Byl jeden...“. Orientaci v textu pohádkového příběhu zjištujeme otázkami, které směřujeme k vyhledání události, či událostí v příběhu. „S kým si Honza u rybníčka povídal?; „Komu Honza plátno prodal?“; „Kolikrát žádal Honza vrbu, aby zaplatila?". Honza byl trochu přihlouplý, po zjištění této informace dokáže žák vyvodit odpověd’ na otázku „Proč prodal plátno právě vrbě?" a sdělit svůj názor na přičinu Honzova jednání se závěrem „Měl dobré srdce.". Žák je na úrovni nízké čtenářské gramotnosti, dokáže interpretovat nenáročný text lidové pohádky a určit i hlavní myšlenku. Žákům pomůžeme otázkou: „Jak pohádka skončila?" Honza byl v závěru odměněn za své dobré srdce, ale o jeho odměně rozhodla náhoda.

Tento text využijeme i pro rozvíjení střední úrovně čtenářské gramotnosti. Žák na pokyn vyučujícího samostatně vyhledává popsané události, reprodukuje své zjištění a je schopen vyvodit z textu závěry. "Jak reagoval táta, když zjistil, že Honza nepřinesl za plátno peníze?"; "Proč se Honza vrátil zpátky k vrbě?"; „Vyhledej a řekni, proč se Honza dostal s vrbou do sporu o prodané plátno."; "Proč se dal Honza s vrbou do křižku?“; „Proč ležela vrba najednou na zemi?" Žák vyvozuje bezprostřední závěry, dokáže vysvětlit, co vedlo pohádkovou postavu Honzy k takovému jednání. Jaké pocity pohádkový hrdina měl, když našel v kořenech vrby hrnec s penězi. "Překvapeni."; "Dostal to, na co měl právo."; "Prožil zadostiučiněni." Neopomíjíme také pracovat se základními jazykovými prostředky a zaměříme se u lidové pohádky na vyhledávání a vysvětlování slov a slovních spojení, které Ize charakterizovat jako archaismy (byl ušlý) a historismy (tolar, dukát) či lidová rčení (vytrhnout se z bídy). Využíváme otázek typu: "Vysvětli slovo tkadlec. “; „Jak rozumíš slovu ztrouchnivělá?"; "Co znamená - dost se ošívali?" nebo „Honza se popadl s vrbou do křížku?" Pozornost věnujeme i označení hlavní postavy pohádky scharakteristickým jménem Honza. V závěru textu pohádky najde žák zmínku o vypravěči pohádky. Poslední věta mu naznačí, jak odpovědět na otázku: „Kdo pohádku vyprávěl?"

Poměrně obtížným literárním textem k rozvíjení čtenářské gramotnosti je adaptovaná pohádka Františka Hrubína O Popelce, v níž v překladu využil motiv pohádky Charlese Perraulta Popelka aneb Skleněný střevíček ${ }^{11}$. Vysokou úroveň čtenářské gramotnosti má při čtení tohoto pohádkového textu žák prokázat při rozpoznávání a vyhledávání podstatných skutečností a detailů, které jsou zmiňovány na různých místech literárního textu a dokázat interpretovat a integrovat informace a myšlenky. Pohádka je náročnější také rozsahem textu (2098 slov) a básnickým jazykem Františka Hrubína.

Vyhledat a rozpoznat podstatné skutečnosti a detaily na různých místech textu, interpretovat je např́klad po tichém čtení, zvládne žák s vysokou úrovní čtenářské gramotnosti na základě vhodných pokynů či zadaných otázek a úloh typu: „Porovnej a vyhledej ty části textu, v nichž se autor zmiňuje o postavách pohádky.";

\footnotetext{
${ }^{10}$ HORÁK, J. Český Honza. Praha: SNDK, 1966. s. 29.

${ }^{11}$ HRUBÍN, F. Śpaliček pohádek. Praha: SNDK, 1957. s. 146.
} 
Porovnej jejich vlastnosti."; "Jaká byla Popelka?"; "Jak se chovala?"; „Jak se Popelka cítila, když se jí sestry vysmály, za to, že chtěla jet také na ples?"; „Jakou roli měli v príběhu myšky, kocour a dýně?" ;”

K jakým závěrům žák došel při posuzování událostí v pohádkovém příběhu, zjistíme, až když žák s přesným odkazem na text interpretuje, jaké vztahy mezi nimi při čtení odhalil. „Co se stalo, když na hodinách zazněl dvanáctý úder?"; „Proč potom Popelka pospíchala z plesu pryč?"; „Co se stalo s kvítkem jeteličku, když ho král zvedl?"; "Jak by príběh pokračoval, kdyby se kvítek jetelíčku neproměnil ve střeviček?" O úrovni čtenářské gramotnosti žáka nás také přesvědčí zjištění, že žák nejenže porozuměl vztahu mezi událostmi, ale že došel i k jistým závěrům, když si uvědomil, jaký význam pro sdělení celého příběhu mají prvky pohádkovosti v kompozici príběhu. Všimne si triády, např. v počtu postav, zaznamená úvodní a závěrečnou formuli, upozorní na nepravděpodobnost děje, místa i času, v nichž se příběh odehrává. A v závěru konstatuje, že dobro zvítězilo a zlo bylo potrestáno. „Všimni si, jaký trest stihl sestry za to, jak se k Popelce chovaly. Proč je autor nepotrestal př́sněji, např. smrtí?" I zde Ize odhalit, do jaké míry došlo u žáka s vysokou úrovní čtenářské gramotnosti, k osvojení literárního textu, k jeho interpretaci, pokud žák dokáže popsat, zda došlo u některých postav pohádky k posunu $v$ jejich charakteru.

Také pocity při jednání zúčastněných pohádkových postav žák odhalí a následně interpretuje na základě pozorné četby textu. Dokáže odpovídat na otázky, v nichž je na takové situace upozorněn. „Proč byly sestry Popelky po plese mrzuté a mračily se“?; „Proč král všem dívkám střevíček osobně zkoušel?"

S odkazem na text by měl být žák schopen rozpoznat jazykové prostředky, které autor v pohádce využil. V popisu Popelčiných šatů žák vyhledá v textu věty, v nichž stařenka kouzlí pro Popelku šaty, a dokáže z těchto vět odvodit, že jazyk vyprávění slouží jako umělecký prostředek.

Ukázka: ...

Popelka se osmělila. „Jak mohu jet v těch hadříčách, co mám na sobě?”

„To už je to nejmenší, " pravila stařenka. „Utrhni tamhle s kaštanu list!"

Popelka šla a ulomila lesklý list, zrovna na něj svítil měsíček. Stařenka se ho dotkla proutkem a v tu chvíli držela Popelka místo listu zlatozelené šaty, vyšivané střibrem.

"A ted' utrhni dva lístky tamhle z jetelíčku!"

Popelka utrhla orosené lístky a stařenka je proutkem proměnila v zelené střevíčky vyšité perličkami.

Zaměříme-li se otázkami na citovaný text, zdůrazníme jinakost jazykového sdělení prostřednictvím autora, jež je známý zejména jako tvůrce poezie pro dětského i dospělého čtenáře. Věty pohádky čteme nahlas i potichu, abychom zdůraznili estetičnost sdělení, a zadáváme úlohy k řešení. „Porovnej barvu kaštanového listu s šaty, které stařenka Popelce vykouzlila."; "Proč byly šaty zlatozelené?"; ,Jaká je souvislost mezi střibrným vyšíváním na šatech a měsíčkem?"; „Proč byly střevičky z listků jetele?"; „Jak souvisí orosený kvítek jetelíčku s vyšivaným střevíčkem perlami?"; „Jaký význam má v popisu Popelčiných šatů přirovnání?"; "Proč autor využil slov citově zabarvených? Najdi je."; "Jaké byly Popelčiny střevičky, když byly lehoučké jako motýlí kukla?"; "Vysvětli, jak rozumís slovnímu spojení -sestry se pýřily-?"; "Všimni si, jak autor slovy, která použil, ovlivnil pohádkové vyprávěni. "; Jak rozumíš myšlence, že autor při psaní pohádky využil básnického sdělení?"

\section{ZÁVĚR}

Vyhledávat v literárním textu informace patří k činnostem, které jsou v kontextu čtenářské gramotnosti pro žáky nejsnazší. Pokud jsou vedeni k vyvozování, předpokládáme, že žáci dokážou zjištěné informace propojit a popř. domyslet i další sdělení, která v literárním textu nejsou explicitně uvedena. Dalším krokem je propojení zjištěných informací, které nejsou v textu výrazně odděleny např. odstavci, ale žáci je dokážou v celém textu identifikovat, opět propojit a následně interpretovat. $V$ souvislosti s tím pak najdou a pochopí i hlavní myšlenku, pokud $v$ textu je dostatečně zřejmá, a při následném posuzování textu zaujmou kritický postoj k textu samotnému. Uvažují o jazykových prostředcích, které autor použil, o úloze literární postavy v príběhu, vyjadřují 
své dojmy a pocity z četby literárního textu, přemýšlí nad vlastní literární tvorbou inspirovanou osvojeným uměleckým textem.

Pokud shrneme všechna předchozí sdělení, můžeme více méně sumarizovat, co vše by si žák měl na různých čtenářských úrovních na písemném textu osvojit z pohledu práce s literárním textem. Je zapotřebí si v souvislosti stím uvědomit, jako roli v rozvoji a podpoře čtenářské dovednosti hraje škola, český jazyk a literární výchova. Problematika porozumění textu, resp. čtenářská gramotnost žáků základní školy je chápána jako důležitá součást didaktiky vzdělávacího oboru český jazyk a literatura. Ale na zvládnutí porozumění textu se pochopitelně podílejí i další vzdělávací obory. Zjištění, která nám předložila Česká školní inspekce po vyhodnocení mezinárodního šetření PIRLS 2016, by nás měla vést k hledání dalších metod a forem práce s uměleckými texty $v$ hodinách literární výchovy na 1. stupni základní školy. Několik metodických doporučení pro práci s textem jsme se pokusili v našem příspěvku nastínit.

\section{PODĚKOVÁNÍ}

Autorka článku děkuje recenzentům za podnětné připomínky a náměty, které pomohly upravit a následně významně zvýšit kvalitu celého předloženého textu.

\section{Zdroje}

[1] BUBENÍČKOVÁ, P. a kol. (2011). Kontexty čtenářství a čtenářské gramotnosti. Hradec Králové: Gaudeamus. ISBN 978-80-7435-165-5.

[2] ČERNÁ, O. (2014). Čtení není žádná nuda. Praha: Portál. ISBN 978-80-262-0720-7.

[3] HAVEL, J., NAJVAROVÁ, V. a kol. (2011). Rozvíjení gramotnosti ve výuce na 1. stupni ZŠ. Brno: MU. ISBN 978-80-210-5714-2.

[4] HEJSEK, L. (2015). Rozvoj čtenářské gramotnosti v procesu základního vzdělávání. Olomouc: UP. ISBN 97880-244-4535-9.

[5] HORÁK, J. (1966). Český Honza. Praha: SNDK.

[6] HRUBíN, F. (1957). Špalíček pohádek. Praha: SNDK.

[7] KRAMPLOVÁ, I. a kol. (2002). Netradiční úlohy aneb Čteme s porozuměním. Praha: Ústav pro informace ve vzdělávání. ISBN 80-211-0416-3.

[8] METELKOVÁ SVOBODOVÁ, R. (2013). Formování čtenářské gramotnosti v prostředí školy se zaměřením na žáky mladšího školního věku. Ostrava: UNIVERSITAS. ISBN 978-80-7646-451-1.

[9] METELKOVÁ SVOBODOVÁ, R. (2008). Čtenářská gramotnost z lingvistického hlediska. Ostrava: UNIVERSITAS. ISBN 978-80-7367-653-6.

[10] METELKOVÁ SVOBODOVÁ, R., HYPLOVÁ, J. (2011). Strategie rozvíjení čtenářské gramotnosti v čítankách 1. stupně ZŠ. Ostrava: UNIVERSITAS. ISBN 978-80-7464-003-2.

[11] Mezinárodní šetření PIRLS 2016, Národní zpráva MŠMT, ISBN 978-80-88087-14-4.

[12] PRŮCHA, J. a kol. (2009). Pedagogická encyklopedie. Praha: Portál. ISBN 978-80-7367546-2,

[13] PRŮCHA, J.; WALTEROVÁ, E.; MAREŠ, J. (2001). Pedagogický slovník. Praha: Portál. ISBN 80-7178-579-2. 